\title{
OCCURRENCE OF TOXOPLASMOSIS AND ITS PREVALENCE IN CATTLE IN THE SOUTH BOHEMIAN REGION
}

\author{
K. HEJLfČKK and I. LITERÁK'
}

${ }^{1}$ Department of Epizootiology, University of Veterinary and Pharmaceutical Sciences, 61242 Brno

Received Fanuary 29, 1992

\begin{abstract}
Hejlíček, K. and I. Literák: Occurrence of Toxoplasmosis and its Prevalence in Cattle in the South Bohemian Region. Acta vet. Brno, 61, 1992: 195-206.

The epizootiological survey of the occurrence of toxoplasmosis in cattle was carried out in one region of the Czech republic during the period of 1979 to 1990 .

A total of 1,934 slaughter animals were examined. The antibodies were detected in the blood serum of the animals in $4.1 \%$ of the cases by SFT (total 1,926 samples), in $1.6 \%$ by CFT (total 1,238 samples), and in $0.5 \%$ by MPA (total 1,673 animals). The parasite itself ( $T$. gondii) was detected by a biological experiment only in one case out of 1,748 examined samples, which equals $0.06 \%$.

A serological monitoring of culled animals was carried out for four years in two herds of 860 and 500 animals. A rapid increase of positive SFT results was found in October $1983(20.0 \%$ and $43.2 \%$ ), in November 1983 (not examined and $90.0 \%$ ), and in January $1984(40.0 \%$ and $50.0 \%)$. The results indicated that an epizootic of toxoplasmosis had occurred. However, no clinical symptoms of the disease were detected, neither an increased occurrence of abortions.

A total of 218 samples of bovine blood serum was examined from 8 small farms with different animal species. SFT was positive in $22.5 \%$, CFT in $3.4 \%$, and MPA in $0.5 \%$ of the examined samples. The detected antibody titres were low, mostly 4 in SFT, and also their prevalence was short, mostly 3 to 6 months. The occurrence of the SFT antibodies was most frequent in summer (in July) - $36.8 \%$ - apparently as a result of contamination of the environment by the oocysts of the young cats, born in spring and recently infected by $T$. gondii.

A total of 2,266 calves was examined during 5 years. The calves were divided into groups by their age. In the animals 10 to 21 days old the SFT antibodies were found in $2.8 \%$ of the cases, in 3 months old animals in $1.9 \%$ and in 6 months old animals in $1.0 \%$. It can be anticipated that the antibodies were mostly of the colostral origin. On the other hand, the occurrence of the antibodies, detected by CFT, increased with age within the same age groups $(0.2 \%, 2.9 \%$, and $25.1 \%)$.

The hygienic and epidemiological danger of toxoplasmosis in cattle is very small. Also the epizootiological importance of cattle as a source and means of transmission of $T$. gondii is minimum.
\end{abstract}

Toxoplasma gondii, cattle, Sabin-Feldmann test (SFT), complement-fixation test (CFT), microprecipitation in agar gel (MPA), monitoring, housing system

Toxoplasma gondii belongs to the most widespread pathogenic protozoa. It affects large numbers of various species of homoithermic vertebrates, including the domestic animals. The definitive hosts are cats of the family Felidae. From this source the parasite propagates by various direct and indirect ways to other animal species.

The objective of this work was to concentrate on the revealing of the epizootiological status and the importance of the toxoplasmosis in cattle. The long-term monitoring was made in the district of Strakonice by means of examination of slaughter cattle, cattle housed under various conditions, and the various age groups of calves of large number of farms.

Extensive references on the occurrence and prevalence of toxoplasmosis in cattle were summarized in the monograph by Dubey and Beattie (1988). The reviews presented by these authors 
show clearly that in the overwhelming majority of the serological examinations of cattle in various countries the specific antibodies against Toxoplasma gondii were detected. The incidence varies between $1 \%$ and $99 \%$, not only by the countries, but also by different areas within the countries. This finding is presented also by the review on the occurrence of CFT antibodies in cattle on the territory of the former USSR, published by Beyer and Shevkunova (1986). Levit and Vustina (1963) found the CFT antibodies in cattle in five co-operative farms of eastern Kazakhstan in $16.1 \%$ to $29.9 \%$.

It is necessary to consider the different serological methods, and their different interpretation by the various authors, when the data on the occurrence of the antibodies against Toroplasma are evaluated from the reference sources. Obviously, the different serological reactions detect different types of the antibodies, and the different stages of the infection. The results of the Sabin-Feldman test (SFT) are questioned in cattle, although SFT is one of the most frequently used methods in the diagnostics of toxoplasmosis. The reason is a low temperature $\left(56^{\circ} \mathrm{C}\right)$, which is used by many authors for inactivation of the cattle serum for SFT, and the consequent nonspecific positive reactions (Dubey 1986). However, many authors agreed in the finding that the antibodies against toxoplasmosis in cattle occur only in low titres and exist only for short time. This finding indicates a low sensitivity of cattle to toxoplasmosis.

Kouba et al. (1974) summarized the data on the occurrence of antibodies against toxoplasmosis in cattle on the territory of Czechoslovakia during the period of 1948 to 1970 . During this period different authors examined the total of 508 samples of bovine blood serum by SFT (including $41.7 \%$ positive findings), 611 samples by complement fixation test (CFT), including $19.7 \%$ positive findings), and 219 samples by the microprecipitation in agar gel (MPA, 219 samples, including $1.7 \%$ positive findings). Later on, Palička at al. (1975) examined by MPA 213 head of slaughter cattle with a positive finding in $5.6 \%$ of the cases. According to Surveillance antropozoonóz CR (The Surveillance of Anthropozoonoses in the Czech Republic) of 1980-1989, totally 2,611 samples of bovine serum were examined on the whole territory of the Czech Republic, including 36 , i. e. $1.4 \%$ of positive findings. The percentage of the positive findings ranged from $0.06 \%$ to $19.2 \%$ in different years.

The low sensitivity of cattle to $T$. gondii is apparent also from the results of the demonstration of the agent in the bovine tissues. According to the review by Dubey and Beattie (1988), only several authors were successful to demonstrate the agent out of the examinations of a large number of samples of bovine tissues. Dubey and Beattie (1988), however, are doubtful as for the demonstration of $T$. gondii from the retina of cattle, as it is mentioned by several authors. The reason of the doubts results from an unsuccessful attempt to demonstrate the parasite in the retina of the experimentally infected cattle. In Czechoslovakia, demonstration of $T$. gondii in the tissues of spontaneously infected cattle was successful only by Čatár et al. (1969), who demonstrated the agent by a biological experiment in 8 animals out of $85(9.4 \%)$ on examination of the brain and the diaphragm. According to the Surveillance of Anthropozoonoses in the Czech Republic there were 52 samples of the tissues of aborted fetuses examined by a biological experiment during 1980-1989. All results were negative.

In order to evaluate the sensitivity of cattle to toxoplasmosis, many experimental infections with different forms of the parasite (tachyzoites, tissue cysts, oocysts) were performed with regard to various ways of infection and various age groups. Rommel et al. (1966) infected calves by various routes using cysts of the strains of $T$. gondii of various origin. In maiority of animals, the demonstration of the agent was only successful until 38 days after the infection. The antibodies, demonstrated by SFT, appeared after 5-14 days, reached peak values after 9-30 days, and were not detected any more after 2-6 months. The infected calves showed temporarily high body temperature, decreased activity, and loss of appetite. Similar results were also obtained by Beverley et al. (1977). Munday (1978) experimentally infected calves and pregnant cows with tachyzoites, tissue cysts, and oocysts. Higher titres of antibodies were demonstrated in the animals infected with oocysts compared to animals infected with the other forms of the parasite. The agent was demonstrated in tissues only in some animals infected by oocysts or tachyzoites. It was also recorded that the virulence of the strain employed influences the occurrence and the intensity of the clinical symptoms after the experimental infection, and the survivability of $T$. gondii in the tissues of the experimental calves (Fayer and Frenkel, 1979, Stalheim et al. 1980a). Dubey (1983) infected experimentally the calves with oocysts and found that 3 and 6 days after the infection there were 10 to 1,000 times more trophozoites of $T$. gondii in their small intestine and mesenterial lymph nodes than in the lungs and the liver. However, between day 6 and 8 after infection, the number of the parasites was reducted 1,000 times within the tissues. The cysts originated already on day 11 and survived up to 287 days after the infection. In the same way $T$. gondii was demonstrated by the same author in the mesenterial lymph nodes and in the small intestine of cows, slaughtered on day 162 and 168 after the experimental infection by oocysts.

Some authors paid attention also to the possibility of transmission of $T$. gondii from mother 
to fetus. Both the etiology of abortions in cattle and the possibility of the circulation within the cattle population, including a possible transmission to other animal species, or humans, were considered. Congenital toxoplasmosis in cattle is described only rarely under natural conditions (Cravero 1980; Zardi et al. 1979). The results of the experimental infections of pregnant cows with T. gondii were not clear as well. Munday (1978) infected pregnant cows per os by the cysts and oocysts of $T$. gondii. There was no infection by $T$. gondii demonstrated in the newborn calves. Stalheim et al. (1980a, b) infected pregnant cows intravenously and intramuscularly by tachyzoites of $T$. gondii and per os by oocysts of Toxoplasma. The demonstration of T. gondii was successful only in fetuses of the animals inoculated into the uterus during the first trimester of the pregnancy. On the other hand, toxoplasmosis was not demonstrated in the calves of cows, infected by the oocysts. Dubey (1983) isolated $T$. gondii only in one out of five calves of the cows that were infected experimentally by oocysts on the day 95-155 of pregnancy. Under natural conditions, i. e. when cattle is infected per os by a small number of oocysts, it can be concluded that intrauterine transmission of $T$. gondii is very rare. It is possible to find reports on increased numbers of abortions in the herds with the prevalence of the antibodies in the majority of the animals (Tainturier et al. 1980). These conclusions, however, are rather empirical, without a proper demonstration of the agent.

The other routes of transmission that were also studied, includied milk and semen. Rommel and Breuning (1967) demonstrated toxoplasmosis only in one mouse out of 2,058 mice, infected by the milk of three experimentally infected cows. Infection took place after consumption of a milk sample, collected on day 8 after the original infection. However, Stalheim et al. (1980a) did not confirm this finding. Skibo and Karpus (1978) mentioned the occurrence of antibodies against toxoplasmosis in calves that suckled milk of the cows recently infected by $T$. gondii. Nevertheless, it is generally accepted that milk of the cows infected by $T$. gondii has a very small importance for transmission of toxoplasmosis (D u bey 1986) examinations of the semen of one experimentally and seven spontaneously infected bulls were also negative (Timofejev 1977).

The aim of our long-term study was to determine the prevalence of toxoplasmosis and the occurrence of antibodies and the agent in cattle in one region of the Czech Republic, considering different systems of housing and different age of the animals. These data should serve for the topical assessment of the epizootological, epidemiological, and hygienici mportance of toxoplasmosis in cattle.

\section{Materials and Methods}

The following examinations were carried out in the district of Strakonice in South Bohemia during the period of 1979 to 1990 :

1. Ten to 15 animals were sampled at a slaughterhouse approximately in the intervals of one month during the whole year (during the period of 1979 to 1990). The following samples were collected: blood, brain, and muscle tissue of the crura diaphragmatica. The samples were taken randomly from animals of various ages, as they were slaughtered.

2. Blood was collected from cows that were culled from two herds of 860 and 500 head during the period of 1981 to 1984 . The sampling took place immediately prior to removal of animals out of the herd.

3. Blood was also collected quarterly on a regular basis from the cows from three small-scale farms during the period of 1981 to 1984 . During the period of 1986 to 1990 , sampling was extended to another five small-scale farms.

4. Blood was collected quarterly on a regular basis from calves a large-scale calf raising operation (1,000 head). Newly arriving groups of calves (40 to 80 animals) were sampled at the age of 10 to 21 days. The same animals were again sampled at the age of 3 and 6 months. The calves were taken from cows of 35 herds, kept mostly in barns with tied housing system for 100 head of cattle.

The serum from the collected blood samples was further examined for the presence of the antibodies against $T$. gondii, using SFT, MPA, and in the part of the cases also CFT. SFT was performed according to the standard guidelines of the Central Veterinary Institute in Prague, Czechoslovakia (serum inactivation at $60^{\circ} \mathrm{C}$ for $30 \mathrm{~min}$.). CFT was performed according to the standard guidelines of the Ministry of Health of the Czech Republic. The biopreparations of ÚSOL, Prague, Czechoslovakia, were used. The basic dilution for SFT was 1:4, for CFT 1:10. MPA was carried out using the kits of ÚSOL, Prague, Czechoslovakia, according to the respective instructions.

Experiments for the $T$. gondii isolation were performed as follows: different tissue samples of the same animal were mixed together in an electric mixer. A fine suspension in buffered physiological saline with antibiotics (600,000 i. u. of penicillin $\mathrm{G}$, and $1 \mathrm{~g}$ of streptomycin per 1,000 ml) was obtained. Each sample was used for administration of $1 \mathrm{ml}$ intraperitoneally to two toxoplasma negative mice. The mice were killed after 5 weeks, if they did not die spontaneously earlier. The 
cysts of $T$. gondii were sought in the compressed mounts of the brain tissue. Moreover, serological examination for the SFT antibodies was made. The demonstration of antibodies in the infected mice was considered as a positive result of the isolation experiment.

\section{Results}

1. A total of 1,934 head of slaughter cattle was monitored. Altogether 1,926 animals were examined by SFT. Out of this number, 80 animals $(4.1 \%)$ were found positive. The respective numbers for the examinations by CFT were 1,238 with 20 positive cases $(1.6 \%$ ), and for MPA 1,673 with 8 positive cases $(0.5 \%)$. The presence of $T$. gondii was demonstrated only in one case out of 1,748 examinations $(0.06 \%)$. The dynamics of the occurrence of antibodies by the years is summarized in Fig. 1 .

Table 1

The occurrence of antibodies against toxoplasmosis in culled cows in 2 large-scale farms in the district a) Herd $\mathbf{R}$. Strakonice

\begin{tabular}{|c|c|c|c|c|c|c|c|}
\hline \multirow{2}{*}{$\begin{array}{l}\text { Year } \\
1981 \\
1982 \\
1983 \\
1984\end{array}$} & \multirow{2}{*}{$\begin{array}{c}\text { Examined cows } \\
103 \\
139 \\
60 \\
65\end{array}$} & \multicolumn{2}{|c|}{ SFT positive $\%$} & \multicolumn{2}{|c|}{ CFT positive \% } & \multicolumn{2}{|c|}{ MPA positive $\%$} \\
\hline & & $\begin{array}{r}1 \\
3 \\
6 \\
14\end{array}$ & $\begin{array}{r}1.0 \\
2.2 \\
10.0 \\
21.5\end{array}$ & $\begin{array}{l}0 \\
0 \\
0 \\
0\end{array}$ & $\begin{array}{l}0 \\
0 \\
0 \\
0\end{array}$ & $\begin{array}{l}0 \\
1 \\
0 \\
0\end{array}$ & $\begin{array}{l}0 \\
0.7 \\
0 \\
0\end{array}$ \\
\hline Total & 367 & 24 & 6.5 & 0 & 0 & 1 & 0.3 \\
\hline
\end{tabular}

b) Herd Ø.

\begin{tabular}{|c|c|c|c|c|c|c|c|}
\hline Year & Examined cows & \multicolumn{2}{|c|}{ SFT positive $\%$} & \multicolumn{2}{|c|}{ CFT positive $\%$} & \multicolumn{2}{|c|}{ MPA positive $\%$} \\
\hline $\begin{array}{l}1981 \\
1982 \\
1983 \\
1984\end{array}$ & $\begin{array}{r}115 \\
188 \\
109 \\
66\end{array}$ & $\begin{array}{r}1 \\
6 \\
53 \\
20\end{array}$ & $\begin{array}{r}0.9 \\
3.2 \\
48.6 \\
30.3\end{array}$ & $\begin{array}{l}0 \\
0 \\
6 \\
1\end{array}$ & $\begin{array}{l}0 \\
0 \\
5.5 \\
1.5\end{array}$ & $\begin{array}{l}0 \\
1 \\
0 \\
0\end{array}$ & $\begin{array}{l}0 \\
0.5 \\
0 \\
0\end{array}$ \\
\hline Total & 478 & 80 & 16.7 & 7 & 1.46 & 1 & 0.21 \\
\hline
\end{tabular}

SFT - Sabin-Feldman test (titre $\geq 4$ )

CFT - Complement fixation test (titre $\geq 10$ )

MPA - Microprecipitation in agar gel

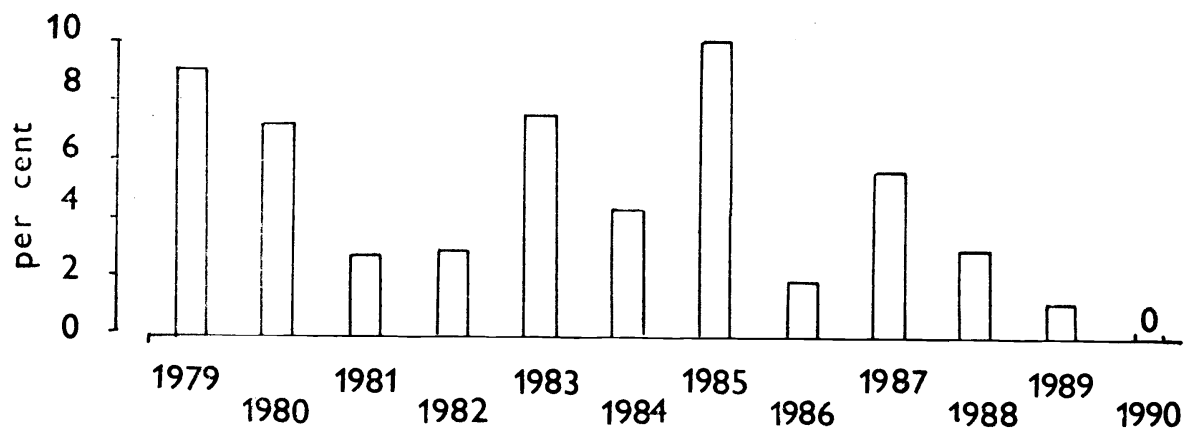

Fig. 1: The occurrence of the antibodies against toxoplasmosis (SFT) in slaughter cattle in the district Strakonice $(n=1,926)$

SFT - Sabin-Feldman test (titre $\geq 4$ ) 
2. Altogether 367 culled cows were examined by SFT, CFT and MPA in the herd R., and 478 culled cows in the herd C. (Tab. 1a, 1b, Fig. 2). While during 1981 and 1982 the percentage of the serologically positive cases corresponded to the long-term average (SFT in the herd R. $-1.0 \%$ and $2.2 \%$; in the herd C. $0.9 \%$ and $3.2 \%$ ), a considerable increase of the positive results of SFT occurred. in October and November 1983, and in January $1984(20.0 \%$, not examined, and $40.0 \%$, in the second case $43.2 \%, 90.0 \%$ and $50.0 \%$ ). Moreover, positive results of CFT occurred in the herd C.

3. Altogether 218 samples of blood serum were examined from the selected small-scale farms (Tab. 2). All age groups of cattle were involved. The numbersof examinations by the different methods were following: SFT - 218 samples, CFT - 176 samples, and MPA - 209 samples. The antibodies were demonstrated in 49,6 , and 1 sample, respectively, i. e. in $22.4 \%, 3.4 \%$ and $0.5 \%$ of the. cases. In two out of eight monitored small-scale farms no antibodies against: toxoplasmosis were demonstrated in the serum samples. In these two farms. (No. 1 and 4) only small numbers of examinations were carried out (10 and 9 samples of blood serum, respectively). In the remaining 6 small-scale farms, antibodies against $T$. gondii were found.

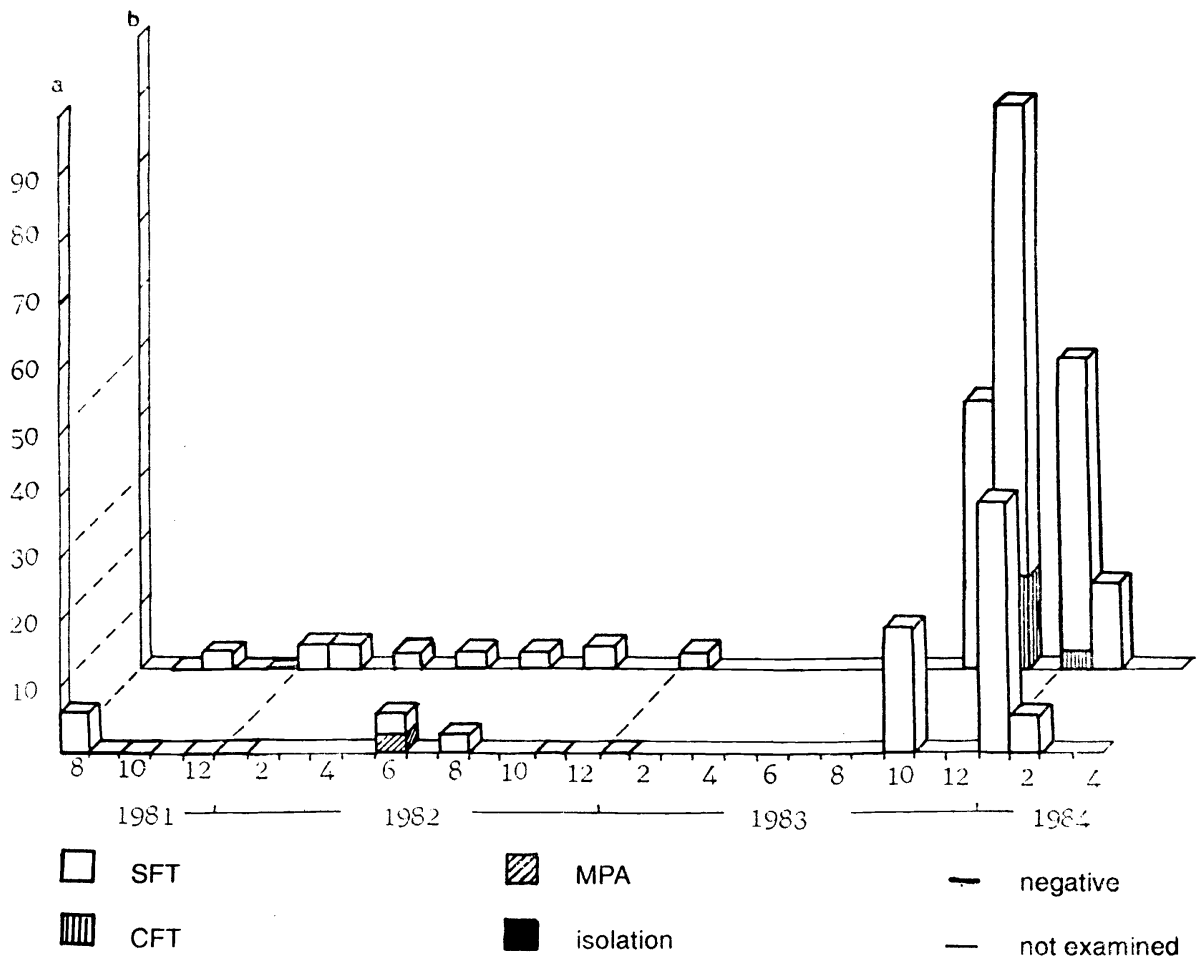

Fig. 2.: Dynamics of the occurrence of the antibodies against toxoplasmosis in cows from 2 large-scale farms in the district Strakonice CFT - complement fixation test (titre $\geq 10$ )

MPA - microprecipitation in agar gel 
Table 2

The occurrence of antibodies against toxoplasmosis in cows in small-scale farms of the district of Strakonice

\begin{tabular}{|c|c|c|c|c|c|c|c|c|}
\hline Farm & $\begin{array}{l}\text { Monitoring } \\
\text { period }\end{array}$ & $\begin{array}{c}\text { Number of } \\
\text { examinations }\end{array}$ & \multicolumn{2}{|c|}{ SFT positive } & \multicolumn{2}{|c|}{ CFT positive } & \multicolumn{2}{|c|}{ MPA positive } \\
\hline $\begin{array}{l}1 \text { (R., V.) } \\
2 \text { (M., R.) } \\
3 \text { (M., V.) } \\
4 \text { (K., R.) } \\
5 \text { (A., K.) } \\
6 \text { (K., N.) } \\
7 \text { (L., T.)! } \\
8 \text { (V., S.) }\end{array}$ & $\begin{array}{c}1981-1984 \\
1982-1984 \\
1981-1984 \\
1986 \\
1986-1989 \\
1986-1990 \\
1986-1990 \\
1986-1990\end{array}$ & $\begin{array}{r}10 \\
10 \\
19 \\
9 \\
27 \\
7 \\
36 \\
100\end{array}$ & $\begin{array}{r}0 \\
4 \\
3 \\
0 \\
6 \\
2 \\
10 \\
24\end{array}$ & $24.0 \%$ & $\begin{array}{l}0 \\
0 \\
0 \\
2 \\
4\end{array}$ & $4.0 \%$ & $\begin{array}{l}0 \\
0 \\
0 \\
0 \\
0 \\
0 \\
0 \\
1\end{array}$ & $1.0 \%$ \\
\hline Total & & 218 & 49 & $22.5 \%$ & $6^{*}$ & $3.4 \%$ & $1^{* *}$ & $0.5 \%$ \\
\hline
\end{tabular}

* Number of samples: 176

** Number of samples: 209

The titres of antibodies that were detected (Tab. 3) were very low, mostly 4 at SFT, and only rarely 16, or 32. The persistence of antibody levels was also short-term, mostly only 3 to 6 months. In some animals there were no antibodies detected during the monitoring that lasted for one year or more, or the antibodies were detected only rarely and for a short time.

The seasonality of the findings was as follows: Winter - a total of 54 examinations with 6 positive cases $(11.1 \%)$, spring - 56 examinations with 13 positive cases $(23.2 \%)$, summer - 57 examinations with 21 positive cases (36.8\%), autumn -51 examinations with 9 positive cases (17.6\%), all SFT (Fig. 3).

4. It was proven by regular monitoring of the selected groups of calves of various ages (Tab. 4) that antibodies against toxoplasmosis are present in their blood serum. In calves of the first age group (10 to 21 days) the antibodies can be considered as of a colostral origin. The numbers of positive cases in this age group were following (out of the total of 823 examinations): SFT - 23(2.8\%), CFT $-2(0.2 \%)$. The numbers of positive cases out of the total number of 750 calves,

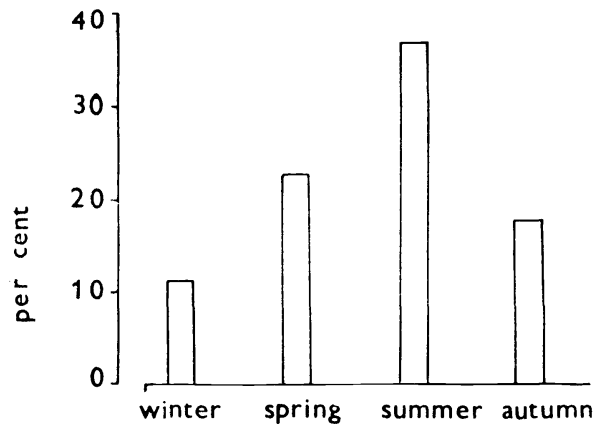

Fig. 3: Dynamics of the occurrence of the SFT antibodies against toxoplasmosis in cattle in the small-scale farms in the seasons of the years $1981-1990$

$(\mathrm{n}=218)$.

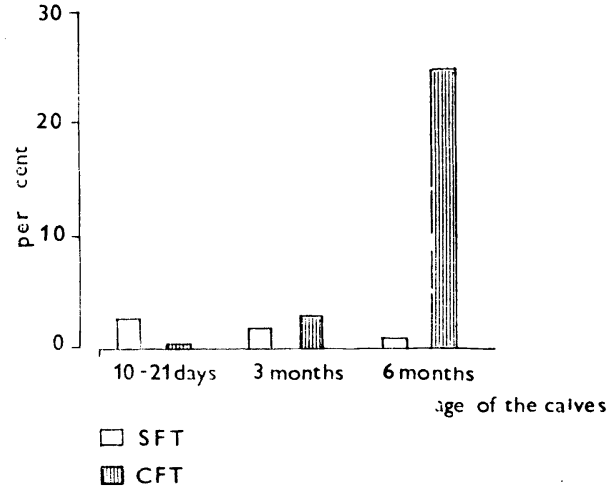

Fig. 4: Dynamics of the occurrence of the antibodies against toxoplasmosis in calves in thre lage-scale calf raising operation during the years $1986-1990$ $(\mathrm{n}=2,266)$ 


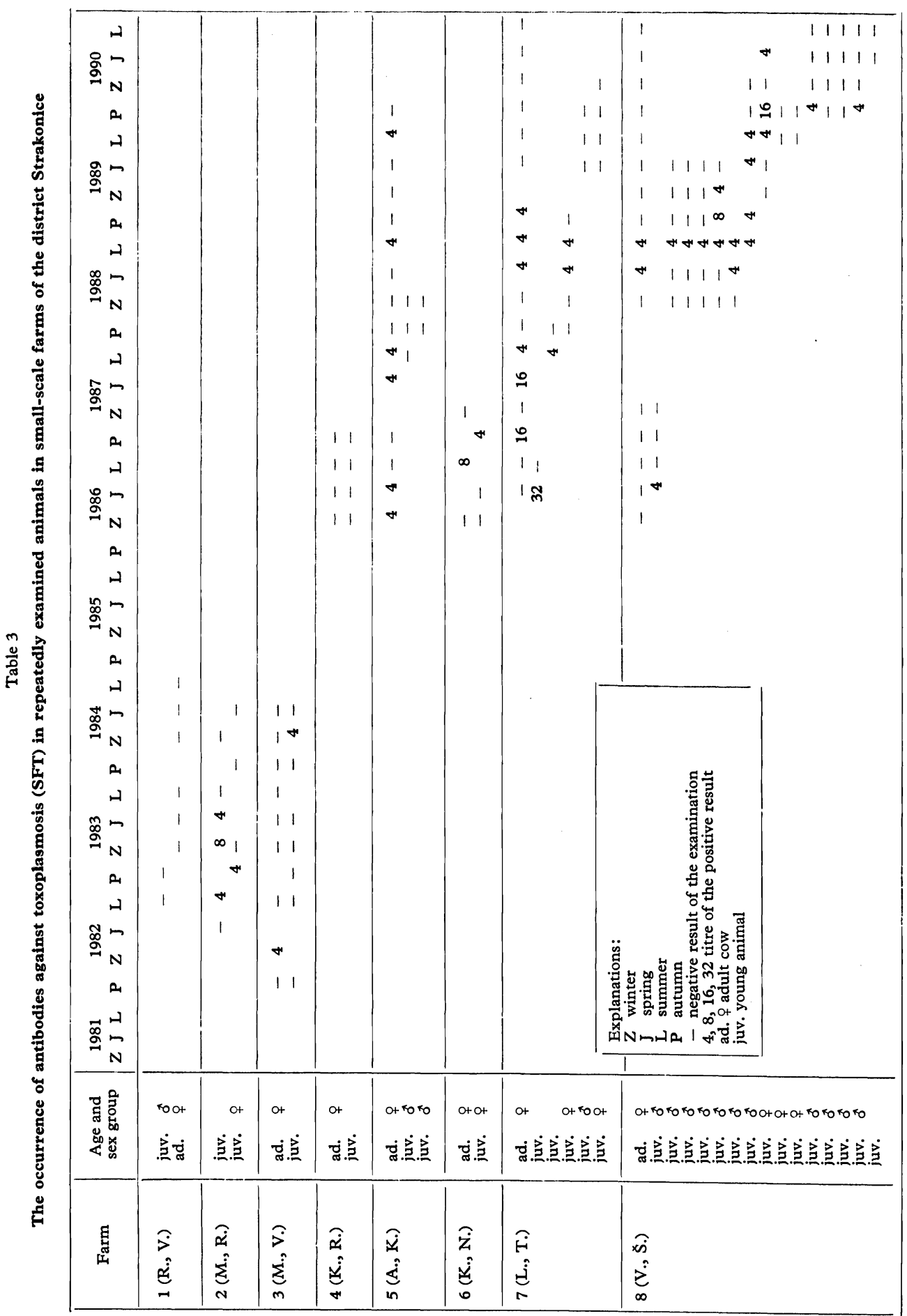


Table 4

The occurrence of antibodies against toxoplasmosis in calves in large-scale raising facility

\begin{tabular}{|c|c|c|c|}
\hline Age of the calves & $10-21$ days & 3 months & 6 months \\
\hline & \multicolumn{2}{|c|}{ number of examined/number of positive SFT/CFT } \\
year & $240 / 5 / 0$ & $226 / 2 / 7$ & $228 / 0 / 51$ \\
1986 & $148 / 9 / 0$ & $139 / 1 / 1$ & $131 / 1 / 34$ \\
1987 & $160 / 4 / 1$ & $151 / 5 / 0$ & $157 / 4 / 26$ \\
1988 & $160 / 5 / 0$ & $157 / 3 / 9$ & $152 / 2 / 58$ \\
1989 & $120 / 0 / 1$ & $77 / 3 / 5$ & $20 / 0 / 4$ \\
1990 & & $750 / 14 / 22$ & $688 / 7 / 173$ \\
& $(28 / 23 / 2$ & $(1.9 / 2.9)$ & $(1.1 / 25.1)$ \\
\hline
\end{tabular}

examinated the age of 3 months were following: SFT $-14(1.9 \%)$, CFT -22 $(2.9 \%)$. In the 688 examined calves of the age of 6 months there were 7 positive cases of SFT $(1.0 \%)$, and 173 positive cases of CFT (25.1\%). Consequently, the numbers of the positive cases of SFT decreased with the age of the calves, and on the other hand, the numbers of the positive cases of CFT increased (Fig. 4). The results were positive totally in 44 cases of SFT (2.0\%) and 197 cases of CFT $(8.7 \%)$.

\section{Discussion}

The antibodies against toxoplasmosis were demonstrated by SFT in $4.1 \%$ out of 1,926 examined animals belonging to a large monitored group of 1,934 slaughter cattle. This value is somewhat higher than the average of $1.4 \%$, recorded by the Surveillance of Anthropozoonoses in the Czech Republic for the period of 1980 to 1989. It should be mentioned, however, that a higher percentage of positive serological reactions was found in the region also in the human population (Surveillance of Anthropozoonoses, 1985). On the other hand, in comparison to older examinations from the period of 1948 to 1970, as summarized by Kouba et al. (1974), the percentage of serologically positive cases detected in this work by SFT, CFT and MPA, was considerably lower (4.1\% compared to $41.7 \%, 1.6 \%$ compared to $19.7 \%$ and $0.5 \%$ compared to $1.7 \%$, respectively). A considerable improvement of the epizootiological situation in cattle toxoplasmosis in the eighties compared to the previous period of 1948 to 1970 can be explained by a higher level of the hygiene of animal housing and feeding in large-scale operations, and especially by limited access of the domestic cat to herds as a final host of T. gondii. We succeeded for the second time in Czechoslovakia (after Čatár et al. 1969) to demonstrate $T$. gondii in tissues of slaughter cattle, although only in a single case out of 1,748 animals $(0.06 \%)$ that were examined by the biological experiment. It means that the possibility of $T$. gondii transmission to humans by bovine tissues cannot be completely ruled out. However, this way of the transmission is apparently not likely. This conclusion conforms to the results by Rommel et al. (1966), Munday (1978), Dubey (1986) and others.

A considerable increase of the positive results of SFT, and partly also of CFT, was observed in October and November 1983, and in January 1984, after two years (1981 and 1982) of low numbers of serologically positive cases in culled cattle of the two large-scale farms. An enzootic outbreak of the infection apparently took place in both herds in the mentioned period. The direct source remained 
undetected. This exacerbation influenced also the relatively high averages of the SFT positive animals in both herds during the period of the monitoring $(6.5 \%$ and $16.8 \%$ ) compared to slaughter cattle. The explanation can be found in the occurrence of a potent source of $T$. gondii in the environment. However, it is interesting that both herds, where the epizootic of toxoplasmosis occurred simultaneously, were about $8 \mathrm{~km}$ apart. The origin of the enzootic cannot be explained by the local conditions, i. e. closer or more intensive contact with the domestic cat, apart from the fact that no population of young cats, very sensitive to the infection with T. gondii, exists in the autumn months. An important finding was the lack of disorders of the health status in cows during the epizootic. Also more frequent abortions were missing. In this respect our findings do not correspond to the field observations of Tainturier et al. (1980), who recorded increased numbers of abortions in cows in similar epizootiological situations.

The antibodies against toxoplasmosis were demonstrated considerably more frequently in small-scale farms than in slaughter cattle originating exclusively from large-scale farms. The difference has a high statistic significance $\left(\chi^{2}, \mathrm{P}<\right.$ $<0.001$ ) for SFT. The reason can be found in the probability of a more frequent contact with the domestic cat and excreted oocyst. This assumption can be supported by the varying numbers of positive samples of bovine serum among the small-scale farms, and the varying occurrence in the different years. The results are apparently connected with the different numbers of cats presented at the small-scale farms, their different age, and the seasonality of the births of kittens. This relation can be clearly found also in the dynamics of the occurrence of antibodies against toxoplasmosis in cattle during the seasons of the year. The lowest occurrence was in winter (January $11.1 \%$ ). The number of positive cases of SFT increased in spring (April - 23.2\%), and culminated in summer (July - 36.8\%). The majority of kittens is born in spring. They are soon infected by $T$. gondii from the environment contaminated by the cat population, and excrete huge amounts of cysts during the intestinal phase of the disease. The maximum contamination of the environment of the small-scale farms by oocysts occurs therefore at the end of spring and during summer. The oocysts enter the organism of cattle with the green feed and cause production of the antibodies. It can be assumed that oocyst numbers decrease in autumn and analogically, the percentage of serologically positive animals is lower $(17.6 \%)$.

A repeated and sometimes long-term monitoring of the animals in the small-scale farms enabled us to confirm the observations of Rommel et al. (1966), Munday (1978), and others who mentioned that antibodies against toxoplasmosis occur in cattle only during a short time period and in low titres. As we demonstrated in several animals that the antibodies occurred repeatedly or during a long time period, a possibility of reinfections should be considered under the field conditions. Anyway, the titres of antibodies and their persistence in monitored animals show that bovine have a low sensitivity to the infection of $T$. gondii.

A certain picture of the prevalence of toxoplasmosis in cattle population can be made according to the occurrence of antibodies in the blood of calves. Almost only colostral antibodies can be expected in the calves 10 to 21 days old. Therefore, also the percentage of positive cases in this work - $2.8 \%$ by SFT - more or less corresponds to the occurrence of antibodies in slaughter cattle $(4.1 \%)$. It should be considered that because of the low titres of antibodies not all of the infected cows form such a level of antibodies in their colostrum that would 
enable a detectable level in the blood of the offspring after their first consumption of the colostrum. This applies especially to those cases when the calves drink smaller amounts of colostrum, or when the colostrum was drunk for a longer time after parturition when its content of antibodies is lower. In average, the percentage of calves with antibodies against toxoplasmosis detected by SFT decreased with age $(3$ months $-1.9 \% ; 6$ months $-1.0 \%)$. This decrease agrees with the colostral origin of detected antibodies. When the occurrence of antibodies detected by SFT somewhat increased in some groups at the age of 3 and 6 months, or remained on the same level, it was necessary to consider a possible postnatal infection by oocysts from the environment. Also the infection by the milk of the dam cannot be ruled put. However, concerning the observed general dynamics of SFT, these cases will be rare. The dynamics of antibodies detected by CFT was completely opposite. In the youngest calves the occurrence of the CFT antibodies was only $0.2 \%$, but with advancing age their percentage increased $(3.0 \%$ and $25.1 \%)$. The increase was highly significant $\left(\chi^{2}, P<0.001\right)$. There is no explanation so far for this finding. Some nonspecific reactions, caused e. g. by other infections by protozoa, could be considered. However, we have no parasitological data to support this presumption.

It can be concluded that the sensitivity of cattle towards toxoplasmosis is low. The frequency of infection by $T$. gondii depends on the possibility of a direct or indirect contact with the principal host - the domestic cat.

\section{Výskyt a rozšíření toxoplazmózy u skotu v jižních Čechách}

V průběhu let 1979-1990 jsme sledovali epizootologickou situaci ve výskytu toxoplazmózy skotu na území okresu Strakonice v České republice.

V souboru 1934 kusů jatečného skotu mělo v krevním séru protilátky prokazované SFR 4,1\% z 1926 vyšetřených zvířat, KFR 1,6\% z 1238 vyšetřených a MPA $0,5 \%$ z 1673 vyšetřených zviŕat. Pouze v jednom prrípadě ze 1748 vyšetřených $(0,06 \%)$ byl biologickým pokusem prokázán původce $-T$. gondii.

Při čtyřletém sérologickém vyšetřování vyřazovaných krav ve dvou kravínech s kapacitou 860 a 500 zvířat byl zjištěn prudký vzestup pozitivity SFR v řínu $1983(20,0 \%$ a 43,2 \%), v listopadu 1983 (nevyšetřováno a 90,0 \%) a v lednu $1984(40,0 \%$ a 50,0 \%). To svědčí pro probíhající toxoplazmovou enzootii. Při tom nebyly u ustájených krav pozorovány klinické príiznaky onemocnění, zejména zvýšený počet abortů.

Při vyšetření 218 vzorků krevního séra skotu v 8 sledovaných malých chovech s různými druhy zviŕat byla zjištěna pozitivita $S F R$ ve 22,5 , KFR ve 3,4 a $M P A$ v $0,5 \%$. Zjištované titry protilátek byly nízké, při SFR většinou 4 , a rovněž jejich trvání bylo krátkodobé, většinou 3-6 měsíců. $V$ průběhu roku byl nejčastější výskyt SFR protilátek - 36,8 \% - v létě (červenec), zřejmě jako důsledek kontaminace prostředí oocystami mladých koček narozených na jaře a čerstvě infikovaných $T$. gondii.

V souboru 2266 telat vyšetřených $\mathrm{v}$ průběhu 5 let ve skupinách podle stáŕí byly $\mathrm{v}$ kategorii $10-21$ dnů starých zvírat nacházeny SFR protilátky ve $2,8 \%$, u stejných zviŕat ve stáríi 3 a 6 měsíců v 1,9 a 1,0\%. L.ze předpokládat, že se jednalo hlavně o kolostrální protilátky. Naproti tomu výskyt protilátek prokazovaných KFR ve stejných věkových kategoriích s věkem vzrůstal $(0,2,2,9$ a $25,1 \%)$. 
Z hlediska hygienického a epidemiologického představuje toxoplazmóza skotu pouze velmi malé riziko a rovněž epizootologický význam skotu jako zdroje a šiřitele $T$. gondii je nepatrný.

\section{Наличие и распространение Т. gondii крупного рогатого скота В южной Чехии}

В ходе длящегося в течение 1979 - 1990 гг. эксперимента исследовали эпизоотологическую ситуацию и значение токсоплазмоза крупного рогатого скота на территории одного района. Из 1934 голов боенского скота установили в кровяной сыворотке антитела, выявляемые SFR $4,1 \%$ у 1926 исследуемых животных, KFR 1,61\% у 1238 исследуемых и МРА $0,5 \%$ у 1673 исследуемых животных. Только в единственном случае из 1748 исследуемых голов $(0,06 \%)$ биологическим экспериментом выявили возбудитель - T. gondii.

В двух коровниках вместимостью 860 и 500 голов в ходе четырехгодичных серопогических исследований отбракованных коров к концү 1983 и в начале $1984 \mathrm{rr}$. был выявлен стремительный рост позитивности SFR (октябрь 20 и 43,2 \%, ноябрь не исследовано и 90,0\%, и январь 1984 40,0 и 50,0 \%), свидетельствующий о протекающей токсоплазменной энзоотии. При этом у содержащихся коров не были выявлены клинические признаки заболевания, в особенности увеличение численности абортов.

В ходе исследований 218 образцов кровяной сыворотки в 8 исследуемых небольших группах с разными видами животных установили позитивность SFR 22,5\%, KFR 3,4 \% и MPA 0,5 \%. Выявляемые титры антител были низкие, при SFR большей частью 4, а также их продолжительность была незначительной, в большинстве 1-2 квартала. В течение года чаще всего имело место наличие SFR антител - $36,8 \%$ летом (июль), по все вероятности как результат сильного заражения среды испражнениями маленьких кошек, рожденных весной и сразу же инфицированных $T$. gondii. У 2266 телят, исследуемым по группам по возрасту в течение 5 лет в категории возраста 10 - 21 сутки находили антитела SFR в 2,8\%, у одинаковых животных в возрасте 3 и 6 месяцев - в 1,9 и 1,0 \%. Следует предположить, что речь шла главным образом о молозивных антителах. В противовес этому, наличие антител, выявлыемых $\mathrm{KFR}$ с возрастом үвеличивалось $(0,2,2,9$ и 25,1\%). процента).

Токсоплазмоз крупного рогатого скота с точки зрения гигиены и эпидемиологии является лишь небольшим риском и эпизоотологическое значение крупного рогатого скота в качестве очага и распространителя T. gondii несущественно.

\section{References}

BEVERLEY, J. K. A.- HENRY, L.-HUNTER, D.-BROWN, M. E.: Experimental toxoplasmosis in calves. Res. Veter. Sci., 23, 1977: 33-37.

BEYER, T. V. - SHEVKUNOVA, E. A.: A review of toxoplasmosis of animals in the U.S.S.R. Veter. Parasit., 19, 1986: 225-234.

CRAVERO, G. C.: Encefalomielite congenita da Toxoplasma gondii in uno vitello. Ann. Fac. Med. Vet., Torino, 24, 1980: 144-153. 
ĊTÁR, G. - BERGENDI, L.- HOLKOVÁ, R.: Isolation of Toxoplasma gondii from swine and cattle. J. Parasit., 55, 1969: 952-955.

DUBEY, J. P.: Distribution of cysts and tachyzoites in calves and pregnant cows inoculated with Toxoplasma gondii oocysts. Veter. Parasit., 13, 1983: 199-211.

DUBEY, J. P.: A review of toxoplasmosis in cattle. Veter. Parasit., 22, 1986: 177-202.

DUBEY, J. P. - BEATTIE, C. P.: Toxoplasmosis of Animals and Man. CRC Press, Boca Raton, Florida, 1988.

FAYER, R. - FRENKEL, J. K.: Comparative infectivity for calves of oocysts of feline coccidia: Besnoitia, Cystoisospora, Sarcocystis and Toxoplasma. J. Parasit., 65, 1979: 756-762.

KOUBA, K. - JÍRA, J. - HƯBNER, J.: Toxoplazmóza. Avicenum, Praha, 1974.

LEVIT, A. V.-VUSTINA, U. D.: Toksoplazmoz selskochozjajstvennych životnych i ptic vostočnogo Kazachstana po rezultatam RSK. Parazity selskochozjajstvennych životnych Kazachstana, Alma-Ata, AN Kaz. SSR, 2, 1963: 181-185.

MUNDAY, B. L.: Bovine toxoplasmosis: experimental infections. Int. J. Parasit., 8, 1978: 181 to 185.

PALIČKA, P. - MÍČEK, E. - KEǨKA, J.: Výskyt toxoplazmózy u lidí a hospodářských zvírat. Veterinářství, 25, 1975: 457-458.

ROMMEL, L. - SOMMER, R. - JANITSCHKE, K. - MÜLLER, I.: Experimentelle Toxoplasma-Infektionen bei Kälbern. Berl. Münch. tierärztl. Wschr., 79, 1966: 41-45.

ROMMEL, M.-BREUNING, J.: Untersuchungen über das Vorkommen von Toxoplasma gondii in der Milch einiger Tierarten und die Möglichkeit der laktogenen Infektion. Berl. Münch. tierärztl. Wschr., 80, 1967: 365-369.

SKIBO, V. N.-KARPUS, L. A.: Eksperimentalnyj toksoplazmoz krupnogo rogatogo skota. Dostiženije veter. nauki peredovogo opyta - životnovodstvu, 1978, 4: 62-64.

STALHEIM, O. H. V.-HUBBERT, W. T. - BOOTHE, A. D. - ZIMMERMANN, W. J.HUGHES, D. E. - BARNETT, D. - RILEY, J. L. - FOLEY, J.: Experimental toxoplasmosis in calves and pregnant cows. Amer. J. veter. Res., 41, 1980a: 10-13.

STALHEIM, O. H. V.-FAYER, R. - HUBBERT, W. T.: Update on bovine toxoplasmosis and sarcocystosis, with emphasis on their role in bovine abortions. J. Amer. veter. med. Assoc., 176, 1980 b: 299-302.

SURVEILLANCE ANTROPOZOONÓZ V ČESKÉ REPUBLICE. Ústav veterinární osvěty, Pardubice, 1980-1989.

TAINTURIER, D.-FRANC, M.-DORCHIES, P.-DUCOS DE LAHITTE, J.: Toxoplasmose et pathologie de la reproduction chez les ruminants et la truie. Rev. Méd. vétér., 131, 1980: 223-235.

TIMOFEJEV, B. A.: Kliničeskije priznaki toksoplazmoza u bykov - proizvoditelej. Veterinaria, Moskva, 8, 1977: 86-87.

ZARDI, O.-ADORISIO, E.-ALEXANDRI, M. - LILLINI, E.-ALOISI, R.: Konnatale Mißbildung durch Toxoplasmose beim Kalb. Tierärztl. Praxis, 7, 1979: 301-304. 